\author{
Filip Presseisen \\ Uniwersytet Papieski Jana Pawta II w Krakowie \\ ORCID 0000-0001-7504-7493
}

\title{
Muzyka wyrazem duchowości - kilka refleksji na temat korelacji stowa i muzyki w Bachowskim chorale bożonarodzeniowym Lobt Cıott, ihr Christen, allzugleich BWV 732
}

\section{Wprowadzenie}

Znaczenie wpływu warstwy słownej na proces kompozytorski jest powszechnie znane. W przypadku dzieł Johanna Sebastiana Bacha można zaryzykować stwierdzenie idealnego odzwierciedlenia słów w świecie dźwięku. W jego twórczości organowej źródłem poszczególnych opracowań są luterańskie pieśni. Celem niniejszego rozważania jest zaprezentowanie sposobu, w jaki kompozytor odzwierciedlił muzycznie poszczególne wersy jednej z najbardziej znanych pieśni bożonarodzeniowych. Przyjęta metoda analizy wzajemnych powiązań warstwy literackiej oraz melodycznej użyta jest do wykazania związku słowa i melodii w śpiewie gregoriańskim, stanowiącym jedno ze źródeł powstałego na początku XVI wieku śpiewu ewangelickiego. $Z$ powodu dużej liczby opisywanych odniesień do opracowań, tłumaczeń i wersów poszczególnych pieśni, sugeruje się, by w trakcie czytania spoglądać w załączone przykłady muzyczne. Zapobiegnie to odczuciu pogubienia w labiryncie wzajemnych powiązań słowno-muzycznych.

\section{Muzyka nabożna}

„W nabożnej muzyce Bóg obecny jest zawsze ze swą łaską" ${ }^{1}$. Autorem tego twierdzenia jest sam Bach². Z punktu widzenia współczesnego odbiorcy kultury,

1 Oryg. „Bei einer andächtigen Musik ist allezeit Gott mit seiner Gnaden Gegenwart” (The Cambridge Companion to Bach, ed. J. Butt, Cambridge 1997, s. 256).

2 Cytowane zdanie jest odręczną notatką lipskiego kompozytora. Zapisał ją na marginesie 5 rozdziału 2 Księgi Kronik w swej trzytomowej Biblii w tłumaczeniu M. Lutra, zawierającej komentarze Abrahama Caloviusa. 
którego recepcja konotacji muzycznych ukierunkowana jest często przez zglobalizowany i silnie skomercjalizowany rynek muzyczny, cytat ten łatwo przeoczyć. Nie przyciaga bowiem powierzchownym blaskiem, nie elektryzuje podobnie jak krzykliwy koloryt reklam, w których liczba bodźców przekracza możliwości świadomej percepcji odbiorcy.

Jeśli jednak odpowiednio skupić uwagę, chociażby z szacunku do faktu odręcznego zapisania przez Bacha cytowanego zdania w osobistym egzemplarzu Biblii, pojawi się pytanie: czym jest wspomniana muzyka „nabożna”? W powstałym w 1732 roku leksykonie muzycznym autorstwa Johanna Gottfrieda Walthera można odnaleźć ponad 50 haseł opisujących w sposób encyklopedyczny różnorodne rodzaje muzyki. Ciężko jednak natrafić na definicję pasującą do Bachowskiego cytatu ${ }^{3}$.

Jeśli próbę jego zrozumienia podejmie się na płaszczyźnie zarówno obecności Boga w ludzkim akcie tworzenia muzyki „nabożnej”, jak i „nabożnym” jej wykonywaniu, świadectwo Forkla, odnoszące się do techniki gry lipskiego kompozytora, nabiera innego wymiaru:

Kiedy chciał wyrazić silne afekty, nie czynił tego, jak inni, przez przesadną moc nacisku klawiszy, lecz przez figury melodyczne i harmoniczne, to znaczy: przez wewnętrzne środki wykonawcze ${ }^{4}$.

Kluczową rolę odgrywa wtedy słowo wewnętrzne. Świadomość Bachowskiego świadectwa w muzycznym akcie twórczym sprawia, że wnętrze kompozytora lub interpretatora staje się przestrzenią umożliwiającą doświadczanie Bożej łaski. Wewnętrzne środki wykonawcze nie są więc bezpośrednim źródłem, lecz ścieżką, której początek jest ściśle związany z wymiarem duchowym. W ten sposób muzyka staje się pełnym wyrazem duchowości.

3 Opisane są: Musica, Musica Antica, Arithmetica, Artificialis, Attiva, Canonica, Chorica, Choralis, Chromatica, Combinatoria, Conjuncta, Contemplativa, Diatonica, Didactica, Drammatica, Ecclesiastica, Enharmonica, Figuralis, Fridgora, Harmonica, Historica, Humana, Hyporchematica, Instrumentalis, Manierosa, Melismatica, Melopoetica, Mensurata, Metabolica, Matrica, Mixta, Moderna, Modulatoria, Mondana, Mimica, Naturalis, Occidentaria, Odica, Organica, Pathetica, Piana, Poetica, Politica, Pythagorica, Recitativa, Rhythmica, Signatoria, Sypmhonialis, Theatralis, Tragica, Vocale, Usuale. Zob. J. G. Walther, Musicalisches Lexicon oder Musicalische Bibliothec (Leipzig 1732), Faksimile, Kassel 2001, s. 391-394.

4 „Wenn er starke Affekten ausdrücken wollte that er es nicht wie manche andere durch eine übertriebene Gewalt des Anschlags, sondern durch harmonische und melodische Figuren, das heisst: durch innere Kunstmittel" (J. N. Forkel, Über Johann Sebastian Bachs Leben, Kunst und Kunstwerke, Lipsk 1802, s. 17-18). 


\section{Muzyczna duchowość stowa}

Wśród niezliczonej rzeszy ziemskich kreacji człowiek, stworzony przez Boga na swe podobieństwo, posiada dwie szczególne cechy przyczyniające się do umiejętności tworzenia relacji wyższego rzędu z tych już istniejących. Pierwsza to umiejętność mowy, pozwalająca na bardzo precyzyjną komunikację oraz (rozszerzając mowę o możliwość jej zapisu) przekazywanie konkretnych idei pomiędzy poszczególnymi grupami istot rozumnych, co stanowi podstawę wytworzenia się kultury kumulatywnej ${ }^{5}$. Druga, choć niemożliwe jest jej zbadanie i obiektywnie udowodnienie w ściśle naukowy sposób, drzemie we wnętrzu każdego człowieka i stanowi podstawę duchowego przebudzenia oraz otwarcia na niematerialny wymiar otaczającego świata. Parafrazując św. Augustyna z Hippony, można ją nazwać „ukrytą w sercu człowieka tęsknotą za Bogiem"'.

Połączenie wspólnych płaszczyzn tych cech widoczne jest u św. Jana Ewangelisty: „Na początku było Słowo, a Słowo było u Boga, i Bogiem było Słowo”. Do przyjęcia Słowa potrzeba nie tylko słuchu sprzężonego z rozumem istoty ludzkiej (cecha pierwsza), ale też koncentracji na unikatowej w całym Boskim stworzeniu sferze wewnętrznej duchowości (cecha druga), umożliwiając tym samym zrozumienie słowa oraz przyjęcie Bożej łaski, potrzebnych do celu duchowej ścieżki Nowego Jeruzalem, w którym możliwe będzie postrzeganie prawdziwej rzeczywistości „twarzą w twarz”.

Skoro proklamacja Bożego słowa jest ścieżką prowadzącą do osiągnięcia tego stanu, wynikające z uniesienia ducha zespolenie słowa z melodią tworzy podwaliny metafizycznej celebracji tekstu, w której możliwe staje się doświadczenie przez człowieka Nieskończoności - fenomen ten porusza duszę oraz ma moc jej przemiany (za sprawą łaski Bożej - oczyszczenia ${ }^{9}$ ), posiadając tym samym cechy zjawiska stricte religijnego ${ }^{10}$. Powstała muzyka, opisana przez Bacha mianem „nabożnej”, jest dla odtwórcy kluczem otwierającym go na doświadczenie łaski, wyrażającej się w doświadczeniu głębokiej pokory wobec doskonałości słowno-muzycznego zespolenia, odczuwanego nie tylko za pomocą zmysłów i rozumu.

Jak pisze Jordi-Agustí Piqué i Collado, hiszpański benedyktyn, kompozytor i organista z klasztoru Montserrat:

5 Por. L. Dean, G. L. Vale, K. N. Laland, E. G. Flynn, R. L. Kendal, Human cumulative culture: a comparative perspective, „Biological reviews” 89 (2014) issue 2, s. 284-301.

6 Augustyn z Hippony, Wyznania, tł. Z. Kubiak, Kraków 2018, 1, 1.

$7 \mathrm{~J} 1,1$.

8 Por. 1 Kor 13, 12; $1 \mathrm{~J} \mathrm{3,2.}$

9 Nawiązanie do greckiej idei katharsis.

10 Por. B. Sawicki, W chorale jest wszystko, Kraków 2014, s. 39. 
Z relacji muzyki ze słowem (...) można zrozumieć, że muzyka, w pewnym sensie, staje się pierwszym hermeneutą celebrowanego słowa i w pewien sposób pozwala nam smakować słowo, prowadzi nas do kontemplacji i podziwiania sprawowanej w liturgii Tajemnicy. Wystarczy zwrócić uwage na niektóre melodie gregoriańskie, aby dostrzec, jak intymna jest tam więź melodii z tekstem i jak mądrze muzyka podkreśla znaczenie tekstu. Hymnodia gregoriańska, z rozkładem tonów i swymi zmianami wyraża i tworzy przestrzeń dla refleksji, medytacji (ruminatio) tekstów, które Kościół wkłada w usta wiernych, aby uświęcić czas ${ }^{11}$.

Przykładem wspomnianej więzi jest Graduał Christus factus est pro nobis ${ }^{12}$. Bazuje on na Liście do Filipian, w którym Chrystus, Bóg-Człowiek, przedstawiony jest jako wzór pokory: „uniżył samego siebie, stawszy się posłusznym aż do śmierci - i to śmierci krzyżowej" ${ }^{13}$. W pierwszej frazie graduału uwypuklony jest zaimek nobis. Zabieg ten wynika z medytacji tekstu biblijnego. Święty Paweł pisze o uniżeniu Chrystusa aż do śmierci, lecz w oryginalnym tekście brak sformułowania pro nobis. Zostało ono dodane przez twórcę graduału dla zwrócenia uwagi, że uniżenie Chrystusa pełni zbawczą rolę dla nas. Związek słowno-muzyczny w tym przypadku polega zarówno na zastosowaniu melizmatu, jak i użyciu rozszerzonych neum. Zabieg ten jest widoczny w warstwie graficznej już na pierwszy rzut oka.

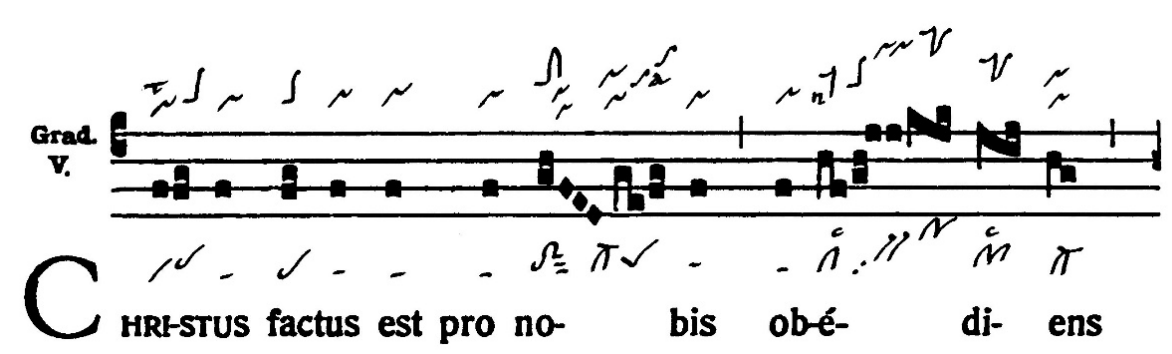

Przyktad 1. Graduat Christus factus est pro nobis

(Graduale Novum, t. 1, Regensburg 2011, s. 108, 3)

11 B. Sawicki, W chorale..., dz. cyt., s. 39, cyt. za: J. Piqué Collado, Teología y música. Una contribución dialéctico-trascendental sobre la sacramentalidad de la percepción estetica del misterio, Roma 2006, s. 37.

12 Śpiew międzylekcyjny.

13 Flp 2, 8. 


\section{Stowo tworzy melodię}

Powyższy przykład dotyczy tradycji gregoriańskiej. Jak wygląda muzyczno-słowne zespolenie w przypadku „nabożnej muzyki” Bacha? Jednym z głównych jej filarów jest śpiew ewangelicki ${ }^{14}$. Będący następstwem Reformacji, utrzymany w języku narodowym, śpiew zboru miał za zadanie zwiększać wśród wiernych znajomość katechizmu, Starego Testamentu oraz Ewangelii. Pomocą służyły łatwe do zapamiętania melodie, będące często kontrafakturami. Zgodnie z postulatami Marcina Lutra (de facto - byłego augustiańskiego mnicha wykształconego w tradycji śpiewu gregoriańskiego), muzyka w tej tradycji traktowana jest jako jedna z najwyższych form sztuki (zaraz po teologii), gdzie „tekst, nuty, akcent i melodia oraz sposób ich realizacji muszą wyrastać z języka ojczystego i jego fleksji”"

Kluczowe znaczenie dla melodii i jej wewnętrznego podziału na mocne i słabe impulsy miała więc nie tylko gramatyka języka niemieckiego ${ }^{16}$, lecz także odmienna w stosunku do łaciny akcentacja podkreślająca w wyrazach pierwsze sylaby. Stworzone w ten sposób melodie często idealnie współgrały z tekstem, szczególnie w zakresie akcentowanych sylab. Niezwykła trudność przekładu niemieckich pieśni ewangelickich na inne języki jest więc logiczną konsekwencją wymienionych uwarunkowań. Widać to w poniższym zestawieniu oryginału jednej z najstarszych pieśni bożonarodzeniowych autorstwa Nikolausa Hermana - Lobt Gott, ihr Christen alle gleich ${ }^{17}$

14 Użycie pojęcia „chorał protestancki” jako narzędzia hymnologicznego w ewangelickim obszarze konfesyjnym może być uznane za nieprecyzyjne i błędne. Jak pisze M. Pilch: „Pojęcie «chorał protestancki» (...) odnosi się do części repertuaru pieśniowego kościołów [pisownia oryginalna - F. P.] protestanckich, jednak granice klasyfikujące pieśń jako chorał są płynne i nieprecyzyjne. Pojęcie to nie jest też zupełnie poprawne ani jednoznaczne. Zakwestionować można zarówno zasadność nazywania pieśni «chorałami», jak i stosowanie określenia «protestanckie» w odniesieniu do pieśni wywodzących się w większości z tradycji Kościoła Ewangelicko-Augsburskiego (luterańskiego)" (M. Pilch, Chorat protestancki - historia, próby definicji oraz konteksty pojęcia, „Notes Muzyczny” 2017 nr 2, s. 49).

15 T. Georgiades, Music and language. The Rise of Western Music as Exemplified in Settings of the Mass, Cambridge 1982, s. 58.

16 Mam na myśli pieśni ewangelickie opracowane później przez Bacha, stąd skupienie na języku niemieckim.

17 Melodia została opracowana przez Bacha w kantacie Süßer Trost, mein Jesus kömmt BWV 151 przeznaczonej na trzeci dzień świąt Bożego Narodzenia, kantacie weselnej Dem Gerechten muß das Licht BWV 195, chorałach BWV 375, 376 oraz zbiorze Orgebüchlein jako BWV 609. Zob. P. Williams, The Organ Music of J. S. Bach. II - Works based on Chorales, Cambridge 1980, s. 34-35. Por. J. Stalmann, 27 - Lobt Gott, ihr Christen alle gleich w: Liederkunde zum Evangelischen Gesangbuch, Hrsg. G. Hahn, J. Henkys, Bd. 13, Göttingen 2005, s. 16-22. 
z polskim przekładem, umieszczonym w Śpiewniku ewangelickim pod tytułem Chrześcijanie, wystawiajcie ${ }^{18}$.

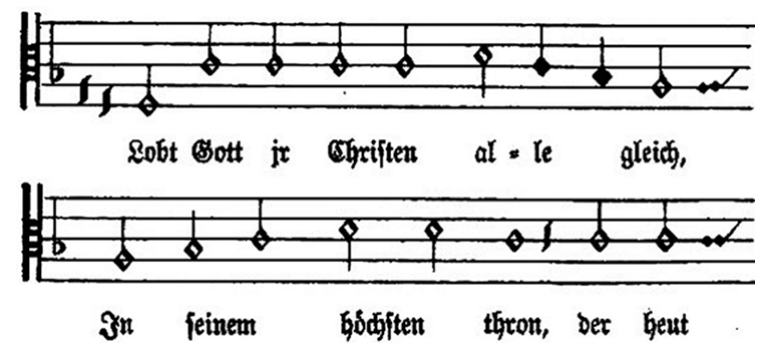

Przykład 2. Pieśń Lobt Gott, ihr Christen alle gleich

(N. Herman, Die Sonntags-Evangelia von Nicolaus Herman (1561), Hrsg. R. Wolkan, Lipsk 1895, s. 28)

Widoczny na początku skok o interwał kwinty - w tradycji śpiewu gregoriańskiego maksymalny spotykany ambitus dwudźwiękowej neumy pes - ze słowa lobt $t^{19}$ na Gott $^{20}$ wzmacnia równocześnie rolę przedtaktu oraz podkreśla drugie słowo. Sposób rozłożenia akcentów w niemieckim zdaniu „Wysławiajcie Boga wszyscy" jest następujący: Lobt Gott, ihr Chri-sten al-le gleich. Zauważalne jest idealne zespolenie akcentacji sylab z melodią oraz podziałem na mocne i słabe części taktu - cząstki Gott, Chri, al, gleich umieszczone się na pierwszej i trzeciej mierze.

Polski przekład zawarty w Śpiewniku ewangelickim wygląda następująco:

\section{Chrześcijanie, wysławiajcie}

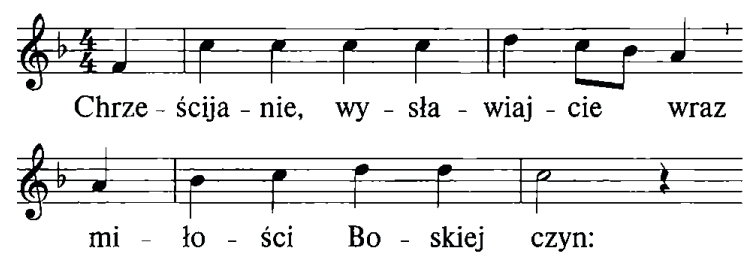

Przykład 3. Przekład pieśni Lobt Gott, ihr Christen alle gleich (Śpiewnik ewangelicki, Bielsko-Biała 2002, s. 72)

W przeciwieństwie do oryginału auftaktowy skok o kwitnę nie łączy dwóch wyrażeń jednosylabowych, przez co nie spełnia funkcji artykulacyjnego wzmocnienia

18 Pieśń nr 39 Chrześcijanie, wystawiajcie, w: Śpiewnik ewangelicki, Bielsko-Biała 2002, s. 72.

19 Niem. „wysławiajcie”.

20 Niem. „Bóg”. 
drugiego dźwięku melodii ${ }^{21}$. Na dodatek liczba sylab nie jest skorelowana z liczbą impulsów rytmicznych ${ }^{22}$. W przypadku zasugerowania się sposobem połączenia trzech pierwszych nut polskiego przekładu pieśni podczas interpretacji preludiów chorałowych zatraca się właściwy charakter prezentowanej melodii, nuty te bowiem są bardzo pomocne w wyznaczeniu sposobu artykulacji ${ }^{23}$.

Nie jest to jednak wina nieprawidłowego przekładu, lecz braku kompatybilności akcentów sylabowych i gramatyki. Źródło trudności tkwi w różnorodności lingwistycznej, o czym świadczy poniższe zestawienie oryginalnego tekstu z dwiema próbami jego przekładu na język polski: barokową i współczesną. Dołączony schemat ukazuje akcenty (pogrubienie), sylaby (cyfry) i wyrazy (łączniki):

Tabela 1. Zestawienie tekstu pieśni Lobt Gott, ihr Christen alle gleich z polskimi przekładami

\begin{tabular}{|l|l|l|}
\hline $\begin{array}{l}\text { Nikolaus Herman } \\
\mathbf{1 5 6 0}\end{array}$ & $\begin{array}{l}\text { Kancjonat pruski } \\
\mathbf{1 7 4 1}\end{array}$ & $\begin{array}{l}\text { Śpiewnik ewangelicki } \\
\mathbf{2 0 0 2}\end{array}$ \\
\hline $\begin{array}{l}\text { Lobt Gott, ihr Christen alle } \\
\text { gleich, }\end{array}$ & Chwalcie Boga chrześcijanie & $\begin{array}{l}\text { Chrześcijanie, wysławiajcie } \\
\text { wraz }\end{array}$ \\
\hline in seinem höchsten Thron, & w Majestacie jego: & miłości Boskiej czyn: \\
\hline $\begin{array}{l}\text { der heut schleusst auf } \\
\text { sein Himmelreich, }\end{array}$ & $\begin{array}{l}\text { Zrządził nam } \\
\text { w niebie mieszkanie }\end{array}$ & $\begin{array}{l}\text { niebiosa dziś } \\
\text { otwiera Bóg, }\end{array}$ \\
\hline und schenkt uns seinen Sohn, & dawszy Syna swego, & zstępuje Jego Syn, \\
\hline und schenkt uns seinen Sohn. & dawszy Syna swego. & zstępuje Jego Syn. \\
\hline
\end{tabular}

21 Warto zauważyć, że ewentualne oddzielenie artykulacyjne wzmocnione jest przez połączenie dwóch sylab zawierających spółgłoski („,b”, „t”, „g”) - Lobt-Gott.

22 Ośmiosylabowe zdanie „Lobt-Gott-ihr-Chri-sten-al-le-gleich” przełożono na dziewięciosylabowe „Chrze-ści-ja-nie-wy-sła-wiaj-cie-wraz”.

23 Uzasadnienie łączenia trzech pierwszych nut w początkowym wersie, będącym oczywistą kontrafakturą bożonarodzeniowego introitu „Puer natus est nobis” pozbawione jest sensu. Ciekawym zagadnieniem wydaje się być jednak sprawa przekładu w Kancjonale pruskim (1741), w którym akcent pada na pierwszą sylabę wersu „Chwalcie Boga, chrześcijanie”. Być może jest to znak żywej tradycji użycia pes quadratum z oryginalnej antyfony.

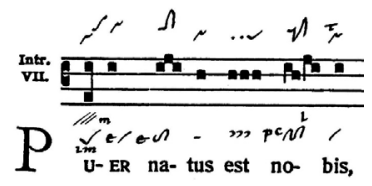

Graduale Novum, t. 1, Regensburg 2011, s. 28.

24 G. F. Rogall, J. H. Hartung, J. Wasiański, Nowo wydany Kancyonat Pruski: Zawieraiący w sobie Wybor Pieśni Starych i Nowych, Z ziemi Pruskiey i Brandenburskiey zwyczaynych, s. 27 (45), https://jbc.bj.uj.edu.pl/dlibra/publication/91645/edition/85236/content (6.05.2020). 


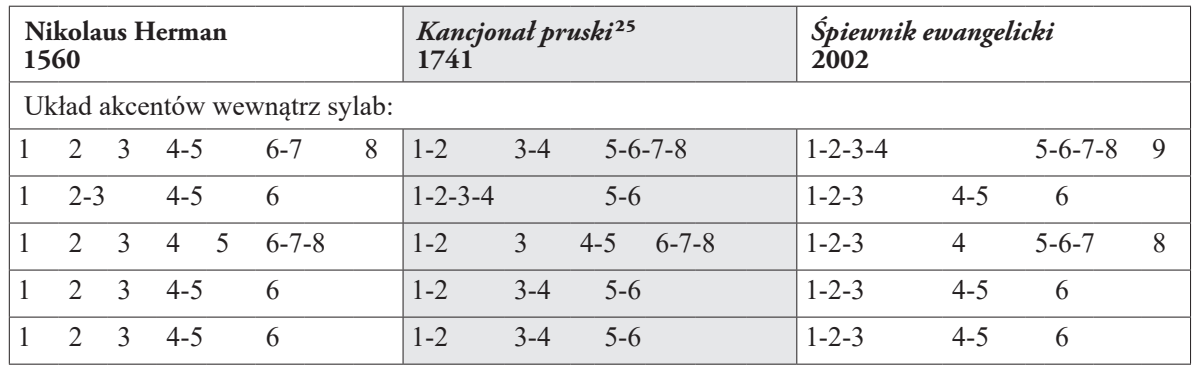

Warto zauważyć ciekawą właściwość oryginalnego tekstu Hermana. W konfrontacji z introitem Puer natus est nobis widoczne jest użycie chiazmu, zmieniającego kolejność użycia źródłowego tekstu antyfony oraz pieśni. Pierwszą oparto o dziewiąty rozdział Księgi Izajasza ${ }^{26}$ oraz początek Psalmu $98^{27}$. W pieśni zaś odwrotnie: początek zaczerpnięto najpierw z Psalmu, dalszą część z Księgi Izajasza.

Uwagę zwraca fakt użycia przez Hermana wersu szóstego (in höchsten Thron koresponduje z Izajaszowym "tronem Dawida"28) w miejsce piątego, będącego podstawą antyfony. Idąc tym tropem, możemy dokonać podobnej - na zasadzie chiazmowej symetrii - zamiany pierwszego wersu Psalmu 98. Efektem jest zestawienie ostatniego wersu Psalmu $97 \mathrm{z}$ incipitem luterańskiej pieśni ${ }^{29}$. Działanie to wydaje się być właściwe z dwóch powodów:

Po pierwsze, zdanie „Lobt Gott, ihr Christen alle gleich” ${ }^{30}$ kierowane jest do chrześcijan. Początek Psalmu 98 nie ma jednak dookreślonego adresata. Zakładając, że Herman użył metody chiazmowego przesunięcia wersetów, ostatni wers Psalmu $97^{31}$ idealnie pasuje do pierwszego użytego w pieśni ${ }^{32}$.

Po drugie, tekst pieśni wykazuje silny związek z luterańską koncepcją „, radosnej wymiany" ${ }^{33}$. Pieśń zawiera bezpośrednie nawiązanie do tej idei w strofie szóstej:

25 G. F. Rogall, J. H. Hartung, J. Wasiański, Nowo wydany Kancyonat Pruski: Zawieraiacy w sobie Wybor Pieśni Starych i Nowych, Z ziemi Pruskiey i Brandenburskiey zwyczaynych, s. 27 (45), https://jbc.bj.uj.edu.pl/dlibra/publication/91645/edition/85236/content (6.05.2020).

26 Treść antyfony zaczerpnięta z Iz 9,5: „Puer natus est nobis, et filius datus est nobis: cuius imperium super humerum eius: et vocabitur nomen eius, magni consilii Angelus” (Graduale Novum, t. 1, dz. cyt., s. 28, 1).

27 Treść antyfony zaczerpnięta z Psalmu 98,1: „Cantate Domino canticum novum: quia mirabilia fecit" (Graduale Novum, t. 1, dz. cyt., s. 1).

${ }_{28}$ Iz $9,6$.

29 Ps 97, 12.

30 Niem. „Chwalcie Boga, chrześcijanie”.

31 „Sprawiedliwi, weselcie się w Panu i wysławiajcie Jego święte imię!”.

32 Dookreślenie adresata: „sprawiedliwi” - „chrześcijanie”, nawiązanie „wysławiajcie” - „chwalcie” w miejsce „śpiewajcie” z Psalmu 98.

33 Niem. fröhliche Wechsel. 
„Er wechselt mit uns wunderlich” oraz siódmej - „Das mag ein Wechsel sein!”34 Symboliczna wymiana ma więc miejsce również na płaszczyźnie literackiej jako skrzyżowanie i przesunięcie o jeden werset biblijnego tekstu źródłowego w gregoriańskim pierwowzorze pieśni.

Tabela 2. Symboliczne nawiązanie do luterańskiej idei radosnej wymiany (chiazm źródeł tekstowych)

w gregoriańskim introicie Puer natus est nobis i ewangelickiej pieśni Lobt Gott, ihr Christen alle gleich

\begin{tabular}{|l|l|l|}
\hline Introit Puer natus est nobis & A = Księga Izajasza 9, 5 & B = Psalm 98, 1 \\
\hline Pieśn Lobt Gott, ihr Christen & B` $^{\prime}(\mathrm{B}-1)=$ Psalm 97, 8 & A` $=(A+1)=$ Księga Izajasza 9, 6 \\
\hline
\end{tabular}

\section{Melodia odpowiada stowu}

Świadomość podziału sylab i akcentów w oryginalnym tekście ewangelickiej pieśni powinno stać się jednym z podstawowych źródeł w procesie interpretacji dzieł powstałych w tradycji ewangelickiej. Jaroslav Pelikan, autor wydanej w 1986 roku książki Bach wśród teologów, napisał:

Preludia chorałowe Bacha na organy są szczególnie fascynującym studium problemu metodologicznego: skomponowane po to, aby antycypować chorał i przygotować go do śpiewania w zborze podczas publicznego nabożeństwa - zgodnie z niedzielami roku kościelnego (...) - znajdują się w dynamicznej relacji z poezją hymnu ${ }^{35}$.

Dynamiczna relacja z poezją może być rozumiana jako:

(...) finezyjna gra dwóch tworzących je linii metrycznych: słownej i muzycznej. Każdą z nich wyznacza układ akcentów realizowanych w ramach określonej matrycy ruchu metrycznego. W przypadku tekstu jest to zastosowana w nim określona miara - w starożytnej poezji greckiej, jak też w hymnach łacińskich była to określona liczba stóp metrycznych. Jedne z nich są akcentowane, inne nie. Tak powstaje ciąg impulsów mocniejszych i słabszych $(\ldots)^{36}$.

34 Różnica między tradycyjnym rozumieniem obecnej już u ojców Kościoła idei zbawczej „wymiany” („admirabile commercium”) a luterańską koncepcją fröhliche Wechsel polega na włączeniu w tę drugą tajemnicy Krzyża i uczynieniu z niej centrum soteriologicznych dociekań. Por. T. Dola, Marcina Lutra soteriologiczna teoria „radosnej wymiany i konfliktu”, „Studia Oecumenica” 17 (2017), s. 133-147.

35 J. Pelikan, Bach wśród teologów, tł. E. Sojka, Katowice 2017, s. 178-179.

36 o. B. Sawicki, W chorale..., dz. cyt., s. 20. 
Logiczną konkluzją jest więc konieczność respektowania tekstu w oryginalnym języku. Uświadomienie rangi formotwórczej związku słowno-muzycznego w melodiach pieśni ewangelickich powinno zatem prowadzić do prób dostrzeżenia bezpośredniego związku sylab ze sposobem kompozytorskiego ich opisania w konkretnych utworach. Dotyczy to oczywiście dzieł wysokiej próby, dlatego zaprezentowany zostanie sposób przełożenia warstwy słownej w kompozycji Johanna Sebastiana Bacha - przygrywce chorałowej BWV $732^{37}$ do wspomnianej pieśni bożonarodzeniowej ${ }^{38}$.

Jej początek przypomina chorał Valet will ich dir geben BWV $736^{39}$. Niezależne od znaczenia symbolicznego motywu tercjowego ważny jest fakt użycia tego sposobu figuracji na pięciu pierwszych dźwiękach pieśni ${ }^{40}$.

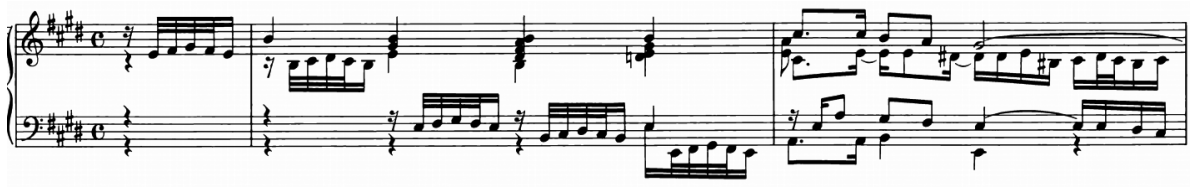

Przykład 4. Przeciwstawienie pojedynczego dźwięku i 5-głosowego akordu na słowa Gott, Christen, allzugleich jako kontrast polaryzacji akordów i figuracji basu (Lobt Gott, ihr Christen, allzugleich BWV 732, t. 1-2) ${ }^{41}$

37 Oryginalny rękopis opracowania nie przetrwał do naszych czasów. Odpis znajduje się w manuskrypcie Mempell-Preller MS x 7 w formie dwóch pięciolinii oraz zbiorze Polschau (Poelchau Mus. MS 39), zawierającym odpisy chorałów bazujące na kopiach z kręgu J. C. Kittela. Zob. P. Williams, The Organ Music..., dz. cyt., s. 275.

38 Wyboru dokonano przed przystąpieniem do pisania niniejszej pracy przez wylosowanie pieśni z polskiego Śpiewnika ewangelickiego. Podjęte ryzyko było świadome: wykazanie niezgodności polskiego przekładu dowolnie wylosowanej pieśni z oryginałem oraz analiza Bachowskiego jej opracowania pod kątem muzycznej symboliki słów ma na celu uwiarygodnić stawiane tezy.

39 Charakterystyczne interludia oddzielające poszczególny wersy, „Lobt Gott, ihr Christen, allzugleich” mogą wskazywać podobny okres powstania utworu do opracowania decjuszowego hymnu Allein Gott in der Höh sei Ehr BWV 715.

${ }^{40} \mathrm{P}$. Williams za pierwowzór figurowanego motywu tercjowego podaje opracowanie „Komm, heiliger Geist” ze zbioru Harmonische Seelenlust G. F. Kaufmanna, jednak moim zdaniem motyw ten został przez Bacha użyty w roli formotwórczej Preludium D-dur BWV 850, którego pierwsza wersja była gotowa przed majem 1720 roku, a więc 13 lat przed powstaniem dzieła Kaufmanna. Por. P. Williams, The Organ Music..., dz. cyt., s. $284-285$.

${ }^{41}$ J. S. Bach, Orgelwerke, Bd. 3: Die einzeln überlieferten Orgelchoräle, Hrsg. H. Klotz, Kassel 1958, s. 64. 


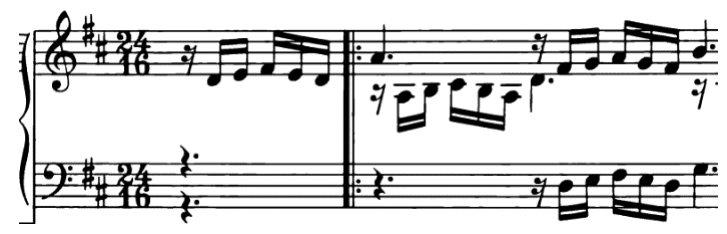

Przykład 5. Valet ich wir dir geben BWV 736, t. $1^{42}$

Są to słowa „Wysławiajcie Boga, chrześcijanie” "33. Możliwa korespondencja motywiczna dwóch pozornie odległych znaczeniowo pieśni związana jest ze świadomym kontrastem pierwszych ich wersów (chwała oddana Bogu versus przekleństwo świata) ${ }^{44}$.

Dialektyka muzyczna nawiązuje do warstwy słownej: pojedynczy dźwięk $\mathrm{h}^{1}$ (słowo $G o t t^{45}$ ) przeciwstawiony jest wielodźwiękowi ulokowanemu na trzeciej mierze taktu (słowo Christen ${ }^{46}$ ). Przeciwieństwo ilości składników (jeden Bóg - samodzielny pojedynczy dźwięk versus pięciogłosowy akord - mnogość chrześcijan) zespolono z akcentem na pierwszą sylabę niemieckiego słowa „chrześcijanie”. Z kolei powtórzenie funkcji dominanty septymowej zapewnia łączność dwóch sylab: Chri-sten.

Następująca po nich zmiana strukturalna odzwierciedla wyrażenie allzugleich ${ }^{47}$. Poprzedzająca je polaryzacja dyszkantowych akordów i figurowanego basu zostaje zastąpiona ruchem ósemkowym, w którym wszystkie głosy posiadają podobny materiał motywiczny.

W ten sposób przygotowane jest wejście drugiego wersu ${ }^{48}$, zrealizowane pomiędzy ostatnią miarą taktu 3 a połową taktu $5^{49}$. Figurowane ósemkowo sylaby sei-nem ${ }^{50}$ akcentuje ustawienie pięciu głosów jako składników toniki, z wyraźnie zaznaczonym akcentem sei-(,je-”), realizowanym ustawieniem akordu na pierwszej

\footnotetext{
42 J. S. Bach, Orgelwerke, Bd. 3, dz. cyt., s. 84.

43 „Lobt Gott, ihr Christen”.

44 Przekład współczesny („Już z tobą się rozstaję, obłudny świecie ty!”) nie oddaje oryginału, znacznie bliższe tłumaczenie zawarto w Kancjonale pruskim („Mą wolą się rozstać, z tobą, chytry świecie”). Zob. Pieśń nr 918 „Już z tobą się rozstaję”, w: Śpiewnik ewangelicki, dz. cyt., s. 1241; G. F. Rogall, J. H. Hartung, J. Wasiański, Nowo wydany..., dz. cyt. s. 518 (536).

45 Niem. „Bóg”.

46 Niem. „chrześcijanie”.

47 Niem. „wszyscy wraz”. Pierwotna wersja tytułu pieśni Hermana ewoluowała, przez co zwrot alle gleich został zastąpiony przez zbitkę allzugleich.

48 „in seinem höchsten Thron”.

49 W polskim tłumaczeniu: „w Majestacie jego” lub „miłości Boskiej czyn” wg przekładu Śpiewnika ewangelickiego oraz Kancjonatu pruskiego. Zob. tab. 1.

50 Niem. ,je-go".
} 
mierze taktu. Z kolei akcent słowa höchsten ${ }^{51}$ polega na użyciu opóźnienia kwartsekstowego w kwintowej pozycji funkcji dominanty.

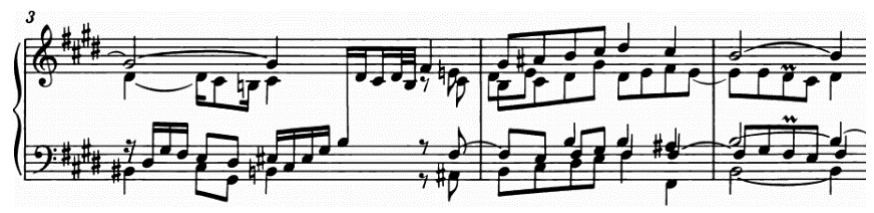

Przykład 6. Augmentacja, akcenty na pierwszych sylabach słów (drugi wers pieśni - „in seinem höchsten Thron”, t. 3-5)

Stopniowa augmentacja prowadzi do półnutowego zaznaczenia najważniejszego wyrazu w wersie - Thron ${ }^{52}$. O ile uzasadnienie dla najwyższego osiaganego punktu melodycznego stanowi melodia pieśni, o tyle widoczne po nim wyjątkowe w skali całego utworu zjawisko zatrzymania trzech głosów w unisonie (o rozpiętości 3 oktaw) wynika z tekstu w sposób pośredni. Wytłumaczeniem fenomenu są dwa sąsiadujące ze sobą biblijne wersety zwiastujące narodziny Zbawiciela: „Ten będzie wielki i będzie nazwany Synem Najwyższego. I da mu Pan Bóg tron Jego ojca Dawida” oraz „I będzie królował nad domem Jakuba na wieki, a jego królestwu nie będzie końca" ${ }^{33}$.

Kierując się tekstem w oryginale, dostrzec można dodatkową korelację 2 i 3 wersu pieśni Hermana w oparciu o końcowy fragment Mowy Szczepana ${ }^{54}$ : „Niebo jest tronem moim, A ziemia podnóżkiem stóp moich; Jaki dom zbudujecie mi, mówi Pan, Albo jakie jest miejsce odpocznienia mego?" 55 . Po jej zakończeniu Szczepan dodaje: „Oto widzę niebiosa otwarte i Syna Człowieczego stojącego po prawicy Bożej" ${ }^{56}$. Wers 4 pieśni mówi zaś o otwarciu nieba ${ }^{57}$. W Bachowskim opracowaniu słowa te - „der heut schleusst auf sein Himmelreich” - ukazane są w szczególny sposób. Melodia przypadająca na sein Himmelreich ${ }^{58}$ prowadzona jest w sopra-

\footnotetext{
51 Niem. „najwyższy”.

52 Ósemki seinen, ćwierćnuty höchsten, półnuta Thron.

53 Łk 1, 32-33.

54 Przy założeniu rozumienia słowa Thron jako „tron”, a nie „czyn” lub „majestat”, jak zostało ujęte w przekładach.

$55 \mathrm{Dz} 7,49$.

$56 \mathrm{Dz} 7$, 56; warto zauważyć, że po wypowiedzeniu tych słów Szczepan został wypchnięty poza miasto i ukamienowany. Tworzy to dodatkową płaszczyznę zrozumienia korelacji tercjowej figuracji początku omawianego utworu z opracowaniem Valet will ich dir geben BWV 736.

57 Niem. „[swe] niebiosa dziś otwiera Bóg”.

58 Niem. „swe niebiosa”.
} 
nie, jednak przedrostek auf ${ }^{59}$ zmienia sposób narracji: melodia pieśni przechodzi do altu za pomocą skrzyżowania głosów w pochodzie h1-a1-e2/fis1-d2-g1.

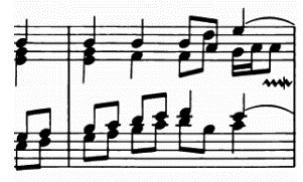

Przykład 7. Przedrostek auf na trzecią miarę (t. 6)

Sopran od tego momentu staje się samodzielną linią melodyczną, dążącą przez półtora taktu do najwyższego dźwięku w całym dziele. Wzmocnienie połączenia słów sein Himmelreich za pomocą auftaktowego ozdobnika słowa sein prowadzi do zakończenia zwrotu na sylabie -reich w altowej półnucie fis ${ }^{1}$. Warto więc zadać sobie pytanie - dlaczego Bach kontynuuje od tego miejsca dalszą narrację, trwającą długość całego taktu?

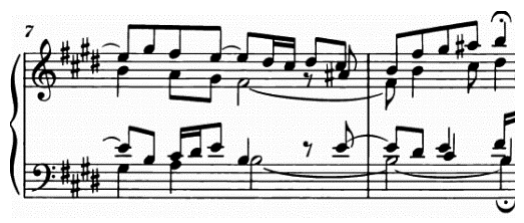

Przykład 8. „Himmelreich” (t. 7-8)

Jak zostało wspomniane, po zbawieniu i osiągnięciu rzeczywistości niebiańskiej staniemy przed Bogiem „twarzą w twarz”. Wskazówką do rozwiązania zagadki jest dokładna analiza melodii sopranu w oparciu o fragment listu św. Pawła: „Teraz widzimy jakby w zwierciadle, niejasno; wtedy zaś twarzą w twarz. Teraz poznaję po części, wtedy zaś poznam tak, jak i zostałem poznany" ${ }^{60}$. Melodia zapisana w nutach jakby $w$ zwierciadle może zostać rozumiana jako odbicie lustrzane. Traktując skrzyżowanie głosów w przedrostku auf jako początek symbolicznego otwarcia niebios (stanowiący również początek zwierciadlanej natury sopranu), w rectusie najwyższego głosu odnaleźć można melodię pieśni Herr Gott! Nun schleuss den Himmel auf ${ }^{61}$.

59 Czasownik „otwierać” w języku niemieckim ma formę rozdzielnie złożoną, składającą się z czasownika podstawowego schliessen oraz przedrostka auf.

601 Kor 13, 12.

${ }^{61}$ Pieśń autorstwa Tobiasa Kiela, oryginalnie przeznaczona na Święto Oczyszczenia Marii Panny (Mariae Reningung), w kręgach pietystycznych odczytywana była jako związana z tema- 
Sposób wyznaczania kolejnych dźwięków melodii w raku jest odbiciem lustrzanym augmentacji poprzedniego wersu. Przedrostek auf jest więc środkiem skrzyżowania się ze sobą dwóch wersów o jednakowym znaczeniu, pochodzących z różnych pieśni $^{62}$. Jest to o tyle ciekawsze, że bezpośrednie podłożenie sylab pod dźwięki skutkuje nałożeniem się akcentowanych części słowa Himmelreich ${ }^{63}$ (sylabizacja altu: schleuss-auf-sein-Him-mel-reich; sopranu: -, auf-mel-Him-den-scheluss-nun) w akordzie e-moll na pierwszą miarę 7 taktu. Dostrzec można jeszcze jedną zbieżność. W omawianym wcześniej opracowaniu BWV 736 pieśni Valet will ich dir geben sposób dojścia do najwyższej nuty (również $\mathrm{h}^{2}$ ) jest identyczny (sekundowy pochód opisujący interwał kwarty pomiędzy dźwiękami fis2-h2) jak w Lobt Gott, ihr Christen, allzugleich. Fakt umiejscowienia kwartowego motywu tuż przed wejściem 5 wersu: „Im Himmel ist gut wohnen” ${ }^{64}$ nie jest więc niespodzianką. Zbieżność motywu kończącego opracowanie wersu trzeciego w Lobt Gott, ihr Christen oraz piątego w Valet will ich dir geben jest wyraźna: wspólny mianownik to niebo ${ }^{65}$.

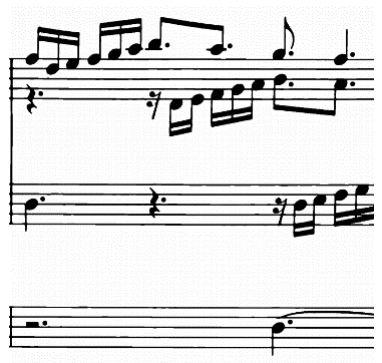

Przykład 9. Dźwięk h² osiągnięty identycznym pochodem tuż przed wejściem słów „Im Himmel” (Valet will ich dir geben BWV 736, t. 30)

tyką śmierci i zmartwychwstania. Por. P. Williams, The Organ Music..., s. 49; Bach opracował ją trzykrotnie: dwa razy jako preludium chorałowe (BWV 1092 i 617) oraz w kantacie Mein Odem ist schwach BWV 222.

${ }^{62}$ Krzyżowanie głosów nie jest w tym przypadku błędem, lecz świadomym zabiegiem kompozytora. Umieszczenie wymiany sopranu i altu dokładnie w miejscu przyimka auf (a więc „otwarcia nieba”) może zwracać uwagę na Krzyż jako niezbędny w drodze do Nowej Jerozolimy.

63 Niem. „niebiosa”.

${ }^{64}$ Niem. „w niebiesiech pragnę mieszkać”. Przekład wg Śpiewnika ewangelickiego z 2002 roku.

65 Opisany motyw kwartowy posiada o wiele szersze konotacje: w zbiorze 36 chorałów w odpisie Neumeistra w opracowaniu Herr Gott, nun schleuss den Himmel auf BWV 1092 pojawia się tuż po słowie Himmel, jak również stanowi jeden z elementów potwierdzających symetryczne ułożenie chorałów Ach, Gott und Herr BWV 714 oraz Als Jesus Christus in der Nacht BWV 1108. 


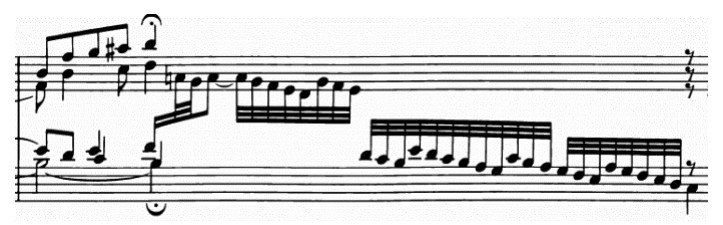

Przykład 10. Dźwięk h2 wyznaczający początek melodii pieśni Herr Gott, nun schleuss den Himmel auf w formie raka; interludium podobne do figuracji z pierwszej części Oratorium na Boże Narodzenie BWV 248 (Lobt Gott, ihr Christen, allzugleich BWV 732, t. 8)

Łącznikiem między symbolem nieba a ostatnim wersem „und schenkt uns seinen Sohn” ${ }^{66}$ jest girlandowy pochód trzydziestodwójkowy, podobny do figuracji początku chóru Jauchzet, frohlocket Weihnachtsoratorium BWV 248 lub pierwszej wariacji kanonicznych BWV 769 na temat bożonarodzeniowej pieśni Vom Himmel hoch da komm' ich her, symbolizujący zstąpienie Boga z nieba i narodziny pod ludzką postacią. Zgodnie z tekstem pieśni, wers ten jest powtórzony dwukrotnie. Za pierwszym razem w tonacji równoległej, za drugim w tonacji zasadniczej. Zastanawiać może użycie wtrąceń akordów zmniejszonych na słowa seinen Sohn ${ }^{67}$. Biorąc pod uwagę koncepcję fröhliche Wechsel, zabieg ten jest w pełni zrozumiały: za pierwszym razem zstąpienie Syna Bożego przedstawiono w kontekście „wymiany” Boga z człowiekiem, rozumianej dosłownie jako narodzenie się Boga pod ludzką postacią, aby ludzie mogli zjednoczyć się z Bogiem ${ }^{68}$. Mówią o tym kolejne zwrotki pieśni: „On się zniżył, jam wywyższony, co to za przemiany!” oraz „Dziwnie się obchodzi z nami przyjmując krewkości, a czyni nas dziedzicami swej Boskiej śliczności”" ${ }^{69}$.

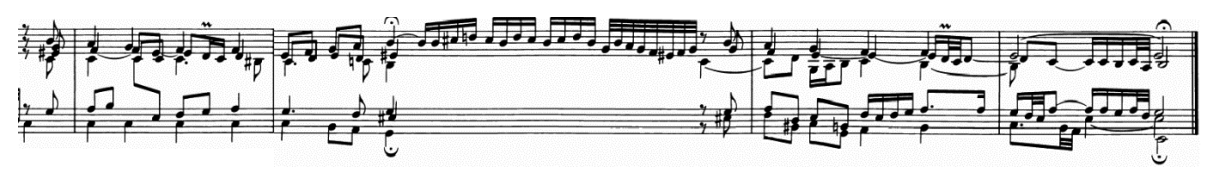

Przykład 11. Wers „und schenkt uns seinen Sohn”, za pierwszym razem w tonacji równoległej z użyciem akordów zmniejszonych oraz charakterystyczną linią basu (t. 8-12)

Linia basu wyprzedza akordowe odzwierciedlenie słowa undi rozpoczyna powtó-

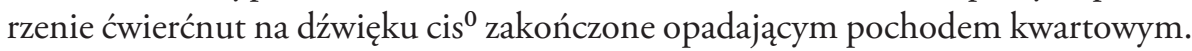

\footnotetext{
66 Niem. „zstępuje Jego Syn”.

67 Niem. „Jego Syn”.

68 T. Dola, Marcina Lutra soteriologiczna..., dz. cyt., s. 146.

69 Przekład początkowych wersów strof 4 („Er wechselt mit uns wunderlich: Fleisch und Blut nimmt er an”) oraz 5 („ Er wird ein Knecht und ich ein Herr; Das mag ein Wechsel sein!”) wg Kancjonatu pruskiego. G. F. Rogall, J. H. Hartung, J. Wasiański, Nowo wydany..., dz. cyt. s. 27 (45).
} 
Po podłożeniu pod nią ostatniego wersu pieśni pochód ten odzwierciedla słowo Sohn ${ }^{70}$.

Idąc tropem polifonicznej niezależności głosów, strukturę basową można postrzegać jako bezpośrednie nawiązanie do pierwszego wersu 3 zwrotki: „Er äußert sich all seiner G'walt". Polski przekład nie pozwala na pełne zrozumienie tego zabiegu, łączy bowiem znaczenie dwóch pierwszych wersów ${ }^{71}$. W przypadku zdania oryginalnego, pierwszy wers traktuje o wyrażeniu mocy („äußert sich Gewalt”), drugi o staniu się „niskim”72 i „niewielkim”73.

Po podłożeniu pod linię basową tego wersu pochód kwartowy odzwierciedli wyrażenie seiner G'walt ${ }^{74}$. Słowo „moc” pada więc dokładnie na najniższy dźwięk (Gis), tworząc podstawę eksklamatywnego akordu zmniejszonego i kontrastując z użytym w takcie 8 dźwiękiem $\mathrm{h}^{2}$, symbolizującym niebo. Pochód, jako inwersja, zestawiony jest na zasadzie dialektycznego przeciwieństwa nieba i mocy Bożej, wyrażającej się w przybraniu ludzkiej postaci - parafrazując znaną polską kolędę Nieskończoność objawia się w przybraniu granic.

Ostatnie wejście melodii w Bachowskim opracowaniu ma radosny charakter. W warstwie słowno-muzycznej zauważyć można połączenie powtórzenia zwrotu „und schenkt uns seinen Sohn” przez ozdobienie słowa seinen ${ }^{75}-\mathrm{w}$ pierwszym pokazie tryl umieszczony jest w miejscu sylaby sei-, w drugim -nen.

\section{Zakończenie}

Jak zostało wykazane, gramatyka i sposób akcentowania wyrazów w języku ojczystym Bacha uniemożliwiają bezpośredni przekład przy zachowaniu jednakowej liczby sylab. Skomplikowane zależności słowno-muzyczne kształtujące sposób komponowania możliwe są do dostrzeżenia dzięki interlinearnemu tłumaczeniu nie tylko słów, ale także poszczególnych sylab. Świadomość tego faktu może znacząco ułatwić interpretację utworów organowych opartych na pieśni ewangelickiej, co więcej, znajomość znaczenia poszczególnych motywów i zabiegów kompozytorskich w opracowaniach chorałowych może przyczynić się do odnalezienia ich w utworach pozornie niezwiązanych ze słowem. Pozostaje żywić nadzieję, że studenci klas organów w procesie edukacji na uczelniach muzycznych zaznajamiani są z ważną rolą związków słowno-muzycznych.

70 Niem. „Syn”.

71 Śpiewnik ewangelicki: „Wyrzeka On się chwały swej, obiera niski stan”; Kancjonat pruski: „Wyniszczył siebie samego, przybrał ze swojej pieczy i kształtu niewolniczego”.

72 Niem. niedrig.

73 Niem. gering.

74 Niem. „swoją moc”.

75 Niem. „Jego". 


\begin{abstract}
Abstrakt
Praca jest próbą odnalezienia szczegółowych zależności słowno-muzycznych w Bachowskim chorale organowym Lobt Gott, ihr Christen, allzugleich BWV 732. Punkt wyjścia stanowi cytat Bacha pochodzący z jego egzemplarza Biblii, traktujący o muzyce określonej jako „nabożna”. Ponieważ analizowany utwór jest opracowaniem luterańskiej pieśni opartej na melodii introitu Puer natus est nobis, wersy pierwszej strofy skonfrontowano z gregoriańską antyfoną. Efektem jest znalezienie chiazmu, widocznego w połączeniu Bachowskiego opracowania trzeciego i czwartego wersu. Przyjęta metoda analizy wzajemnych powiązań słowno-muzycznych pozwala w dalszej części pracy zaobserwować zdumiewającą kompatybilność użytych środków kompozytorskich z poszczególnymi słowami i sylabami, wskazując jednocześnie na wysoki stopień trudności przekładu na inne języki.
\end{abstract}

Stowa kluczowe: Bach; chorał; chorał gregoriański; chorał protestancki; pieśń; pieśń ewangelicka; pieśń luterańska; prozodia; przekład; słowo; śpiew; tłumaczenie

\title{
Abstract \\ Music as a manifestation of spirituality - a few reflections on the correlation between a word and music in Bach's Christmas chorale Lobt Gott, ihr Christen, allzugleich BWV 732
}

This paper is an attempt to find the specific word-and-music interrelations in Bach's organ chorale Lobt Gott, ihr Christen, allzugleich BWV 732. The starting point is the quotation by the composer originated from his Bible in which he described the music as "pious." Since the examined piece is an arrangement of the Lutheran song based on the melody of the introit Puer natus est nobis, the verses of the first stanza have been confronted with a Gregorian antiphon. In effect, a chiasm has been found, noticeable in the combination with Bach's arrangement of the third and fourth verses. The applied method of analyzing the mutual interrelations between words and music allows to observe in further parts of the paper the astounding compatibility of compositional techniques with particular words and syllables to demonstrate at the same time a high degree of difficulty in translating lyrics into other languages.

Keywords: Bach; chorale; Gregorian chorale; protestant chorale; song; evangelical song; Lutheran song; prosody; rendition; word; singing; translation 


\section{Bibliografia}

Augustyn z Hippony, Wyznania, tł. Z. Kubiak, Kraków 2018.

Bach J. S., Orgelwerke, Bd. 3: Die einzeln überlieferten Orgelc

The Cambridge Companion to Bach, ed. J. Butt, Cambridge 1997.

Dean L., Vale G. L., Laland K. N., Flynn E. G., Kendal R. L., Human cumulative culture: a comparative perspective, „Biological reviews” 89 (2014) issue 2, s. 284-301.

Dola T., Marcina Lutra soteriologiczna teoria „radosnej wymiany i konfliktu”, „Studia Oecumenica” 17 (2017), s. 133-147.

Forkel J. N., Über Johann Sebastian Bachs Leben, Kunst und Kunstwerke, Lipsk 1802.

Georgiades T., Music and language. The Rise of Western Music as Exemplified in Settings of the Mass, Cambridge 1982.

Graduale Novum, Regensburg 2011.

Klavierbüchlein für Wilhelm Friedemann Bach, Hrsg. W Plath, Kassel 1962.

Küster K., Musik im Namen Luthers. Kulturtraditionen seit der Reformation, Kassel 2017.

Liederkunde zum Evangelischen Gesangbuch, Hrsg. G. Hahn, J. Henkys, Bd. 13, Göttingen 2005.

Pelikan J., Bach wśród teologów, tł. E. Sojka, Katowice 2017.

Pilch M., Chorat protestancki - historia, próby definicji oraz konteksty pojęcia, „Notes Muzyczny" 2017 nr 2, s. 49-76.

Piqué Collado J., Teología y música. Una contribución dialéctico-trascendental sobre la sacramentalidad de la percepción estetica del misterio, Roma 2006.

Rogall G. F., Hartung J. H., Wasiański J., Nowo wydany Kancyonat Pruski: Zawieraiący w sobie Wybor Pieśni Starych i Nowych, Z ziemi Pruskiey i Brandenburskiey zwyczaynych, https://jbc.bj.uj.edu.pl/dlibra/publication/91645/edition/85236/content (6.05.2020).

Sawicki B., W chorale jest wszystko, Kraków 2014.

Stevenson R., Protestant church music in America. A short survey of men and movements from 1564 to the present, Norton 1970.

Spiewnik ewangelicki, Bielsko-Biała 2002.

Walther J. G., Musicalisches Lexicon oder Musicalische Bibliothec (Leipzig 1732), Faksimile, Kassel 2001.

Williams P., The Organ Music ofJ. S. Bach. II - Works based on Chorales, Cambridge 1980. Zasady pisowni stownictwa religijnego, red. R. Przybylska, W. Przyczyna, Tarnów 2004. 